\title{
PRZYGOTOWANIE WYBORÓW DO SEJMU PRL I KADENCJI W 1952 ROKU JAKO ELEMENT PROCESU SOWIETYZACJI POLSKI PO II WOJNIE ŚWIATOWEJ
}

\author{
Michał Siedziako
}

Instytut Pamięci Narodowej, Oddział w Szczecinie

\author{
ABSTRACT \\ THE PREPARATION OF THE ELECTION TO THE FIRST-TERM SEJM \\ OF THE POLISH PEOPLE'S REPUBLIC IN 1952 AS A PART OF THE \\ SOVIETIZATION PROCESS OF POLAND AFTER \\ THE SECOND WORLD WAR
}

The article is a historical and political analysis of the preparation of the 1952 election to the first-term Sejm of the Polish People's Republic. The electoral system implemented in Poland at that time was based on the electoral practice of the Soviet Union both in general and in many details. According to the Soviet political patterns, the MPs were nominated long before the voting day by the Central Committee of the Polish United Workers' Party, who carefully planned the Sejm composition, both politically and socially. Each candidate had to be verified and nothing was accidental. In an attempt to secure its undivided power, the Communist Party would not let the citizens choose their political representatives. The way in which the Sejm of the Polish People's Republic was elected in 1952 and in later years had very little to do, aside from the name, with free elections, which are invariably at the heart of every democratic political system.

Key words: political system of the Polish People's Republic, elections, Sejm of the Polish People's Republic, Polish United Workers' Party.

Słowa kluczowe: system polityczny PRL, wybory, Sejm PRL, Polska Zjednoczona Partia Robotnicza.

Rok 1952 był okresem kulminacji stalinizmu w Polsce¹. Komuniści, którzy po II wojnie światowej przejęli stery rządów nad Wisłą, zdążyli już umocnić się u wła-

1 Zob. m.in. D. Jarosz, Polacy a stalinizm 1948-1956, Warszawa 2000; Polacy wobec przemocy 1944-1956, red. B. Otwinowska, J. Żaryn, Warszawa 1996; Polacy wobec PRL. Strategie przystoso-

Adres do korespondencji: msiedziako@wp.pl 
dzy, likwidując szereg przeszkód, które im ją ograniczały. Uporano się ze zbrojnym podziemiem niepodległościowym (w czym zasadniczą rolę odegrały jednostki sowieckie ${ }^{2}$ ), którego pozostałości nie stanowiły już dla „rządów ludowych” realnego zagrożenia, rozbito opozycyjne Polskie Stronnictwo Ludowe Stanisława Mikołajczyka i Stronnictwo Pracy Karola Popiela, dopuszczając do legalnej działalności tylko zwasalizowane Zjednoczone Stronnictwo Ludowe, Stronnictwo Demokratyczne i Polską Partię Socjalistyczną, w 1948 roku wchłoniętą przez Polską Partię Robotniczą na Kongresie Zjednoczeniowym, na którym powołano do życia Polską Zjednoczoną Partię Robotniczą ${ }^{3}$ Struktury PZPR dublowały organy administracji państwowej, stając się rzeczywistymi instancjami decyzyjnymi. Wszechogarniająca propaganda, pulsująca kolejnymi wielkimi kampaniami politycznymi (referendum z czerwca 1946 r., wybory do Sejmu Ustawodawczego ze stycznia 1947 r., wspomniany Kongres Zjednoczeniowy, obchody nowych, „ludowych” świąt i rocznic itd.), miała przekonać Polaków, że „ojczyzna światowego proletariatu” stanowi niedościgniony wzór do naśladowania. W różnych obszarach życia społeczno-politycznego i gospodarczego komunistyczna Polska upodabniała się do ZSRS. Nie inaczej było z systemem wyborczym, znaczącym z punktu widzenia kontroli nad całością systemu politycznego.

Choć w Polsce pod rządami PZPR odbywały się cykliczne wybory do władz przedstawicielskich (oprócz Sejmu także do rad narodowych), poza samą nazwą nie miały one jednak wiele wspólnego z instytucją wolnych wyborów, które są jednym z podstawowych wyznaczników demokratycznych systemów politycznych. Konstruując system wyborczy, który miał zapewnić im pełną kontrolę nad Sejmem, polscy komuniści nie byli oryginalni. Tak w zakresie ogólnych rozwiązań, jak i wielu szczegółowych praktyk bazowali na doświadczeniach Związku Sowieckiego, gdzie pomimo z pozoru demokratycznych przepisów prawnych to partia komunistyczna de facto wyznaczała radnych poszczególnych rad, w pełni kontrolując całokształt procedur związanych z wyborami, od wysuwania kandydatów na deputowanych, przez obsadę komisji wyborczych, po samo głosowanie. Do elementów charakterystycznych wyborów w Związku Sowieckim należało m.in. wysuwanie w każdym głosowaniu tylko tylu kandydatur, ile w danych wyborach miało zostać obsadzonych mandatów. Wszyscy kandydaci byli dokładnie selekcjonowani w strukturach partii komunistycznej na podstawie ustalonych w jej kierownictwie parytetów (skład rad miał stanowić odwzorowanie struktury społecznej ludności). To na tym etapie procesu wyborczego dokonywał się w istocie wybór organów przedstawicielskich. Zgłoszenia niezależnych kandydatur były blokowane przez samą partię oraz obsadzony

wawcze, red. G. Miernik, Kielce 2003; H. Świda-Ziemba, Człowiek wewnętrznie zniewolony. Problemy psychosocjologiczne minionej formacji, Warszawa 1998; A. Garlicki, Stalinizm, Warszawa 1993; A. Werblan, Stalinizm w Polsce, Warszawa 2009.

2 Zob. G. Motyka, Na białych Polaków obława. Wojska NKWD w walce z polskim podziemiem 1944-1953, Kraków 2014.

3 O ,porządkowaniu” przez komunistów sceny partyjnej w powojennej Polsce szerzej zob. J. Wrona, System partyjny $w$ Polsce 1944-1950. Miejsce - funkcje - relacje partii politycznych $w$ warunkach budowy i utrwalania systemu totalitarnego, Lublin 1997. 
jej zaufanymi ludźmi aparat wyborczy. Samo głosowanie pozostawało już czystą formalnością, głosujący nie mieli możliwości faktycznego wyboru4.

Po sfałszowanych wyborach do Sejmu Ustawodawczego ze stycznia 1947 roku, do udziału w których dopuszczono jeszcze zwalczaną jednocześnie różnymi metodami (do morderstw politycznych włącznie) opozycję, kolejne wybory w powojennej Polsce również opierać się miały na nakreślonych powyżej zasadach. Ich przeprowadzenie poprzedziło przyjęcie przez Sejm Ustawodawczy Konstytucji PRL, na której projekcie poprawki nanosił sam Józef Stalin ${ }^{5}$.

Konstytucja zawierała ogólne wytyczne w kwestii sposobu przeprowadzania wyborów do Sejmu PRL, głosząc, że są one „powszechne, równe, bezpośrednie i odbywają się w głosowaniu tajnym" (ustawa zasadnicza powtarzała te zasady w dwóch miejscach) ${ }^{6}$. Posłów mieli wybierać obywatele według okręgów wyborczych, przy czym jeden poseł miał przypadać na 60 tys. mieszkańców ${ }^{7}$. Czynne prawo wyborcze przyznano obywatelom, którzy ukończyli 18 lat, nie byli chorzy umysłowo i nie zostali pozbawieni praw publicznych wyrokiem sądu (dodatkowo podkreślano zrównanie praw wyborczych kobiet i mężczyzn, wojskowych i cywilów oraz że przysługują one wszystkim bez względu na „przynależność narodową i rasową, wyznanie, wykształcenie, czas zamieszkiwania, pochodzenie społeczne, zawód i stan majątkowy"). Prawo zgłaszania kandydatów na posłów (obowiązywał ich wyższy cenzus wieku - 21 lat) przyznano natomiast organizacjom politycznym i społecznym zrzeszającym mieszkańców miast i wsi. Szczegółowe rozstrzygnięcia pozostawiono do rozwiązania ustawowego ${ }^{8}$. Analogiczne przepisy zawierała ustawa zasadnicza ZSRS z 1936 roku? .

Opracowanie projektu ordynacji wyborczej kierownictwo PZPR powierzyło komisji, która miała czuwać nad całokształtem spraw organizacyjnych związanych z przygotowaniem wyborów. W jej skład weszli: Józef Cyrankiewicz, Roman Zambrowski i Władysław Dworakowski. Do ich zadań, poza opracowaniem stosownych

${ }^{4}$ Na temat wyborów w Związku Sowieckim szerzej zob. m.in.: G. Brunner, Elections in the Soviet Union [w:] Elections in Socialist States, red. R.K. Furtak, New York 1990, s. 20-52; M.E. Mote, Soviet Local and Republic Elections: A Description of the 1963 Elections in Leningrad Based on Official Documents, Press Accounts, and Private Interviews, Stanford 1965; T.H. Friedgut, Political Participation in the USSR, Princeton 1979, s. 71-154; V. Zaslavsky, R.J. Brym, The Functions of Elections in the USSR, „Soviet Studies” 1978, nr 3, t. 30, s. 362-371; R. Karklins, Soviet Elections Revisited: Voter Abstention in Noncompetitive Voting, „American Political Science Review” 1986, vol. 80, nr 2, s. 449-469.

5 Zob. K. Persak, ,, Troskliwy opiekun i światty doradca Polski Ludowej”. Poprawki Józefa Stalina do Konstytucji PRL z 22 lipca 1952 roku [w:] PRL. Trwanie i zmiana, red. D. Stola, M. Zaremba, Warszawa 2003, s. 187-209.

6 Konstytucja Polskiej Rzeczypospolitej Ludowej uchwalona przez Sejm Ustawodawczy 22 lipca 1952 r., Dz. U. z 1952 r., nr 33, poz. 232, art. 2, 80.

7 Ibidem, art. 16.

8 Ibidem, Rozdział 8: Zasady prawa wyborczego.

9 Zob. Konstytucja (ustawa zasadnicza) Związku Socjalistycznych Republik Radzieckich z dn. 5 XII 1936 r. [w:] A. Bosiacki, H. Izdebski, Konstytucjonalizm rosyjski. Historia i współczesność, Kraków 2013, s. 396-418. 
regulacji prawnych, należało także m.in. przygotowanie projektu podziału kraju na okręgi wyborcze oraz rozpatrzenie listy kandydatów na posłów i ich zastępców ${ }^{10}$.

Przy przygotowaniu przepisów prawa wyborczego szczegółowo analizowano rozwiązania stosowane w innych krajach strefy sowieckiej dominacji ${ }^{11}$. Opierano się na następujących założeniach:

a) że okręgi będą wielomandatowe, a ilość mandatów określona będzie stosownie do Konstytucji (art. 16 ust. 1) według normy 1 poseł na 60000 mieszkańców, b) że będą istniały tylko listy okręgowe (gdyż Konstytucja przewiduje w art. 16 wybór „,według okręgów”), c) że prawo zgłaszania kandydatur, stosownie do art. 86 Konstytucji, będą miały: partie polityczne, związki zawodowe, Związek Młodzieży Polskiej, Związek Samopomocy Chłopskiej, Liga Kobiet, Komitety Obrońców Pokoju (ewentualnie jeszcze organizacje inteligencji twórczej), d) że Partia, stronnictwa polityczne i organizacje masowe zgłoszą w każdym okręgu wspólną listę, e) że zgłoszenie wspólnej listy będzie na odcinku wyborów realizacją hasła Frontu Narodowego, f) że wspólna lista Frontu Narodowego (nazwa oczywiście do ustalenia) będzie faktycznie listą jedyną w okręgu ${ }^{12}$.

Z góry zakładano zatem likwidację choćby formalnego pluralizmu i odebranie wyborcom możliwości jakiegokolwiek wyboru pomiędzy kilkoma listami kandydatów. Było to jednak założenie dotyczące praktyki, bo prawne regulacje dotyczące wyborów miały zachować demokratyczny wydźwięk.

Wzorem dla przepisów, które miały zostać wdrożone w Polsce, była ordynacja wyborcza do Rady Najwyższej ZSRS z 1950 roku. Zasadniczą różnicą była tylko liczba posłów wybieranych w poszczególnych okręgach - w Związku Sowieckim okręgi wyborcze były jednomandatowe, w Polsce z każdego okręgu miało pochodzić po kilku posłów. Nie miało to większego znaczenia praktycznego.

Równocześnie jednak - tłumaczono w tajnej notatce do projektu ordynacji wyborczej - zakłada się, że podobnie jak w ZSRR w okręgu rejestruje się tylko jedną kandydaturę [sowiecka ordynacja wyborcza dopuszczała możliwość rejestracji wielu kandydatów - przyp. M.S.], tak samo u nas głosowanie faktycznie odbędzie się tylko nad kandydaturami zgłoszonymi przez porozumienie (blok) Partii, stronnictw politycznych, związków zawodowych, organizacji społecznych itp., spośród partyjnych i bezpartyjnych w ilości równej ilości mandatów do obsadzenia. Innymi słowy w okręgu będzie tylko jedna lista Frontu Narodowego, obejmująca tyle nazwisk, ile jest mandatów do obsadzenia w danym okręgu. Będzie to więc zastosowany do wielomandatowych okręgów system organizacji wyborów radzieckich. Zapewnia to wybór zarejestrowanych kandydatów Frontu Narodowego - pod warunkiem jednak mobilizacji politycznej (art. 62 ust 2: wymóg udziału w głosowaniu co najmniej połowy wyborców okręgu i uzyskania przez każdego kandydata co najmniej bezwzględnej większości ważnych głosów) ${ }^{13}$.

10 M. Szumiło, Roman Zambrowski 1909-1977. Studium z dziejów elity komunistycznej w Polsce, Warszawa 2014, s. 286; Archiwum Akt Nowych (dalej: AAN), Komitet Centralny Polskiej Zjednoczonej Partii Robotniczej (dalej: KC PZPR), V/17, Protokół nr 176 posiedzenia Sekretariatu BP w dniu 27 VI 1952 r., [b.m. Warszawa], [b.p.].

11 Zob. AAN, KC PZPR, V/21, Informacja o ordynacjach wyborczych do parlamentów w europejskich krajach demokracji ludowej i NRD, [b.m.d.], k. 423-424 [w teczce brak ciągłej paginacji].

12 Ibidem, Notatka w sprawie zasad ordynacji wyborczej do Sejmu Polskiej Rzeczypospolitej Ludowej, [b.m.d.], k. 419.

13 AAN, KC PZPR, V/21, Notatka do projektu ordynacji wyborczej, [b.m.d.], [b.p.]. 
Opracowana w kierownictwie PZPR ordynacja wyborcza została jednogłośnie przyjęta przez Sejm Ustawodawczy 1 sierpnia 1952 roku $^{14}$. Ustawa na wstępie powtarzała zasady biernego i czynnego prawa wyborczego określone w konstytucji. Podkreślono, że każdemu wyborcy przysługuje tylko jeden głos, a głosować można tylko osobiście ${ }^{15}$. Zarządzanie wyborów, nie później niż na miesiąc przed upływem kadencji Sejmu, powierzono Radzie Państwa ${ }^{16}$, w której kompetencje oddano również: podział kraju na okręgi wyborcze, wyznaczenie ich siedzib i przypisanie im odpowiedniej liczby mandatów ${ }^{17}$. Posłowie mieli być wybierani w okręgach wyborczych według konstytucyjnej normy: 1 poseł na 60 tys. mieszkańców ${ }^{18}$. Ustalanie granic obwodów głosowania powierzono prezydiom wojewódzkich, miejskich i powiatowych rad narodowych. Obwody miały obejmować zasadniczo od 1,5 do 3 tys. wyborców, ale mogły być tworzone także dla mniejszych grup obywateli, jeśli najbliższa siedziba obwodowej komisji wyborczej mieściła się ponad $10 \mathrm{~km}$ od ich miejsca zamieszczania, w szpitalach, sanatoriach i innych zakładach służby zdrowia, zakładach opieki społecznej i zakładach inwalidzkich, na statkach i w jednostkach wojskowych ${ }^{19}$.

Do przeprowadzenia wyborów miały zostać powołane: Państwowa Komisja Wyborcza oraz okręgowe i obwodowe komisje wyborcze. Powołanie PKW powierzono Radzie Państwa, pozostałych komisji odpowiednio prezydiom wojewódzkich, miejskich i powiatowych rad narodowych ${ }^{20}$. PKW miała nadzorować przestrzeganie przepisów ordynacji przez komisje niższego szczebla, rozpatrywać skargi na ich działalność, ustalać i ogłaszać wyniki głosowania, rejestrować wybranych posłów i wydawać im zaświadczenia o wyborze, składać Sejmowi sprawozdania z wyborów oraz przedkładać „,wybranej” izbie dokumentację do stwierdzenia ważności aktu wyborczego $^{21}$. Komisjom okręgowym ustawa przypisywała m.in. nadzór nad komisjami obwodowymi, rejestrowanie list kandydatów oraz obliczanie wyników głosowania w okręgach i przekazywanie ich do $\mathrm{PKW}^{22}$. Głównym zadaniem komisji obwodowych było natomiast przeprowadzenie głosowania i obliczenie jego wyników w obwodach, a następnie przekazanie ich do komisji okręgowych ${ }^{23}$.

Ustawa wymieniała szereg podmiotów uprawnionych do zgłaszania list kandydatów na posłów. Mogły to robić organizacje polityczne, zawodowe i spółdzielcze, Związek Samopomocy Chłopskiej, Związek Młodzieży Polskiej oraz inne „masowe

14 Sprawozdanie stenograficzne z 108 posiedzenia Sejmu Ustawodawczego w dniach 31 lipca i 1 sierpnia 1952 r., Warszawa 1952, k. 78 [w:] Sejm Ustawodawczy RP 1947-1952, https://bs.sejm.gov. $\mathrm{pl} / \mathrm{F}$ ?func=file\&file_name=find-nowe-sur\&local_base=ars01 [dostęp: 10.01.2016].

15 Ustawa z dnia 1 sierpnia 1952 r. Ordynacja wyborcza do Sejmu Polskiej Rzeczypospolitej Ludowej, Dz. U. z 1952 r., nr 35, poz. 246, art. 1-5.

16 Ibidem, art. 6.

17 Ibidem, art. 10.

18 Ibidem, art. 9.

19 Ibidem, art. 11-13.

20 Ibidem, art. 14, 18-19.

21 Ibidem, art. 15.

22 Ibidem, art. 16.

23 Ibidem, art. 17. 
organizacje społeczne ludu pracującego"24. Poszczególne podmioty planujące wzięcie udziału w wyborach miały możliwość występowania samodzielnie lub wspólnie ${ }^{25}$, przy czym kandydatury miały być zgłaszane z ich własnej inicjatywy, jak również „spośród osób wysuniętych na zebraniach pracowników w zakładach pracy, na zebraniach gromadzkich, na zebraniach członków rolniczych spółdzielni produkcyjnych, pracowników państwowych gospodarstw rolnych i żołnierzy w jednostkach wojskowych"26. Zgłoszone listy mogły zawierać tylko tylu kandydatów, ilu posłów miało zostać wybranych w danym okręgu ${ }^{27}$. Wyborcy mieli otrzymać możliwość dokonania selektywnego poparcia w ramach jednej z list, którą zdecydowali się wybrać, poprzez wykreślenie z niej wybranych nazwisk ${ }^{28}$. Kandydat, ażeby zostać wybrany, musiał uzyskać bezwzględną większość głosów biorących udział w głosowaniu $\mathrm{w}$ danym okręgu ${ }^{29}$. Aby głosowanie było ważne, musiała w nim wziąć udział minimum połowa uprawionych ${ }^{30}$.

W rozdziale poświęconym przebiegowi głosowania znalazł się zapis stwierdzający, że odbywa się ono bez względu na liczbę zarejestrowanych w okręgu list wybor$\mathrm{czych}^{31}$. Ustawa zabraniała agitacji w lokalu wyborczym. Przewodniczący obwodowych komisji wyborczych czuwać mieli nad utrzymaniem porządku w lokalach oraz nad zabezpieczeniem tajności aktu wyborczego ${ }^{32}$. Szczegółowo opisano wymagane zachowanie wyborcy.

Przed oddaniem głosu - czytamy w ustawie - wyborca okazuje komisji dowód osobisty, a w jego braku legitymację służbową, legitymację związku zawodowego lub inny dokument stwierdzający jego tożsamość. Wyborca nie posiadający dokumentów tożsamości, uznanych przez komisję za wystarczające, może powołać się na świadectwo dwóch wiarygodnych osób, znanych komisji obwodowej. [...] Po otrzymaniu karty do głosowania wyborca udaje się do pomieszczenia za osłoną, gdzie zaznajamia się z kartą do głosowania ${ }^{33}$.

Po dokonaniu ewentualnych skreśleń na karcie wyborca miał wrzucić głos do urny pod okiem komisji w taki sposób, aby „strona zadrukowana nie była widoczna”34. Ustawodawca dawał zatem wyraz szczególnej troski o zachowanie tajności wyborów, co miało jednak niewiele wspólnego z późniejszą praktyką.

Przystępując do ustalania wyników głosowania, obwodowe komisje wyborcze w pierwszej kolejności, na podstawie spisów wyborców, ustalić miały frekwencję wyborczą. Jeżeli lista osób, które według spisu pobrały karty wyborcze, różniłaby się od ilości głosów w urnie, obowiązkiem komisji było wpisanie do protokołu

\footnotetext{
24 Ibidem, art. 33.

25 Ibidem, art. 35.

26 Ibidem, art. 36.

27 Ibidem, art. 39.

8 Ibidem, art. 55.

9 Ibidem, art. 69.

30 Ibidem, art. 73.

31 Ibidem, art. 50.

32 Ibidem, art. 52.

33 Ibidem, art. 54-55.

34 Ibidem, art. 55.
} 
przypuszczalnej przyczyny takiego stanu rzeczy ${ }^{35}$. Kluczowe znaczenie dla praktyki wyborczej miał zapis ordynacji głoszący, że „głos uważa się za oddany na wszystkich nie skreślonych kandydatów i zastępców listy, na którą wyborca głosował" ${ }^{36}$. Oznaczało to, że aby oddać ważny głos, wyborca musiał tylko wrzucić otrzymaną od komisji kartę wyborczą do urny, bez dokonywania jakichkolwiek skreśleń. Protokoły głosowania obwodowe komisje wyborcze przesyłały komisjom okręgowym, a te, po obliczeniu wyników z całego okręgu, do PKW, która po skompletowaniu protokołów z całego kraju miała obliczyć i niezwłocznie ogłosić wyniki wyborów w „Monitorze Polskim" "37.

Ordynacja wyborcza stwarzała zatem formalną możliwość rywalizacji, co miało świadczyć o demokratyczności systemu wyborczego. Jak pisał Andrzej Sadowski, „mimo uchwalenia jej w szczytowym okresie stalinizmu, była bardziej demokratyczna $[\ldots]$ od wszystkich następnych ordynacji" ${ }^{38}$. Rzeczywistość polityczna wykluczała jednak przeprowadzenie na jej podstawie faktycznie demokratycznych wyborów ${ }^{39}$.

Twórcy tego prawa wyborczego - komentował ordynację wyborczą z 1952 roku Lech Mażewski - zakładali, iż w wyniku z zewnątrz sterowanego, jak również głęboko uwewnętrznionego konformizmu, nikt nie skorzysta z uprawnień, jakie dawała powyższa ustawa. I tak się stało. Zresztą w apogeum stalinowskiej ,jedności moralno-politycznej narodu”, wspomaganej terrorem, ale opartej głównie na indoktrynacji, nie mogło być inaczej ${ }^{40}$.

Taki stan rzeczy odpowiadał sowieckiej dychotomii, w której demokratyczne przepisy prawa miały de facto bardzo ograniczony wpływ na kontrolowaną przez partię komunistyczną praktykę wyborczą.

Także nakreślone powyżej przepisy prawa, zachowując pozory demokratyzmu, tworzyły w istocie tylko swoistą fasadę systemu wyborczego PRL. Wyznaczały pewne formalne ramy, w których kluczowe znaczenie miała stosowana praktyka. PZPR kierowała procesem wyborczym w taki sposób, ażeby mieć pełną kontrolę nad składem Sejmu. Mogło to zostać zapewnione dzięki wystawieniu pod głosowanie tylko jednej listy wyborczej, co, jak wspomniano, zakładano już przy konstruowaniu omówionej wyżej ordynacji ${ }^{41}$. Ponieważ przepisy pozwalały na zamieszczanie na listach przedkładanych do rejestracji okręgowym komisjom wyborczym tylko tylu kandydatów, ilu posłów miało zostać wybranych w danym okręgu, wybory do Sejmu PRL I kadencji nie mogły być związane z choćby minimalnym wyborem między

35 Ibidem, art. 59.

36 Ibidem, art. 61.

37 Ibidem, art. 63-71.

38 Cyt. za: W. Sokó1, Systemy wyborcze w Polsce Ludowej - uwarunkowania, mechanizmy i konsekwencje polityczne [w:] Wybory i referenda w PRL, red. S. Ligarski, M. Siedziako, Szczecin 2014, s. 32.

39 Ibidem.

40 L. Mażew ski, System rządów w PRL (1952-1989), Warszawa-Biała Podlaska 2011, s. 69. Zob. również: idem, Posttotalitarny autorytaryzm PRL 1956-1989. Analiza ustrojowopolityczna, WarszawaBiała Podlaska 2011, s. 30-31.

${ }^{41}$ AAN, KC PZPR, V/21, Notatka do projektu... 
kandydatami w obrębie jedynej zarejestrowanej listy Frontu Narodowego - ich liczba musiała się bowiem równać liczbie mandatów do obsadzenia.

Termin wyborów do Sejmu PRL I kadencji został wyznaczony na 26 października 1952 roku $^{42}$. Uchwała Rady Państwa w tej sprawie z 5 sierpnia 1952 roku zawierała również kalendarz wyborczy, określający precyzyjnie, w jakich terminach powinny zostać wykonane poszczególne czynności związane z organizacją wyborów, takie jak m.in. powołanie komisji wyborczych różnych szczebli, rejestracja list kandydatów czy dostarczenie komisjom obwodowym kart do głosowania ${ }^{43}$.

Kluczowe decyzje związane z przygotowaniem wyborów do Sejmu PRL I kadencji zostały podjęte na posiedzeniu Sekretariatu Biura Organizacyjnego KC PZPR ${ }^{44}$ 14 sierpnia 1952 roku. Zadecydowano wówczas o podziale kraju na okręgi wyborcze, między które rozdzielono 425 mandatów, i zatwierdzono stosowne uchwały, formalnie podjęte następnie przez Radę Państwa, oraz rozpatrzono składy personalne PKW i Komitetu Frontu Narodowego (polecono uzupełnić je zgodnie ze „wskazówkami”). Sekretariat BO zaakceptował również plan wydawnictw wyborczych, zalecając zmniejszenie ich ogólnej liczby i zwrócenie szczególnej uwagi na publikacje popularne przeznaczone do agitacji na terenach wiejskich ${ }^{45}$.

Ogłoszenie wspomnianych uchwał Rady Państwa, wdrażających w życie rozstrzygnięcia kierownictwa PZPR, nastąpiło 25 sierpnia 1952 roku. Kraj został podzielony na 67 okręgów wyborczych. W największym z nich, obejmującym Warszawę, miało zostać „wybranych” 15 posłów, w pozostałych od 5 do $10^{46}$. W stosunku do wyborów w 1947 roku liczba okręgów wzrosła zatem o 15, co miało ułatwić kierowanie kampanią wyborczą i dotarcie aktywistów na wszystkie tereny. Przydzie-

42 Kadencja Sejmu Ustawodawczego pierwotnie miała upłynąć w styczniu 1952 r., jednak w grudniu 1951 r., z uwagi na przedłużające się prace nad ustawą zasadniczą, posłowie jednogłośnie (w głosowaniu brało udział 305 posłów, wymagana większość wynosiła 2/3 ustawowego składu izby, a więc 296 głosów) przyjęli ustawę konstytucyjną o jej przedłużeniu o sześć miesięcy; Sprawozdanie stenograficzne z 99 posiedzenia Sejmu Ustawodawczego w dniu 15 grudnia 1951 r., Warszawa 1951, k. 60-62 [w:] Sejm Ustawodawczy RP 1947-1952. Wcześniejsze zarządzenie wyborów do Sejmu PRL nie było możliwe, gdyż nie było podstaw prawnych sankcjonujących jego istnienie, które stworzyła dopiero Konstytucja PRL.

43 Uchwała Rady Państwa z dnia 5 VIII 1952 r. o zarządzeniu wyborów do Sejmu Polskiej Rzeczypospolitej Ludowej, Dz. U. z 1952 r., nr 35, poz. 247.

44 Sekretariat BO KC został powołany do życia wiosną 1950 r. Zdaniem Krzysztofa Persaka najprawdopodobniej powodem jego utworzenia było przejmowanie przez PZPR wzorów organizacyjnych aparatu KC WKP(b). Instancję zlikwidowano na II Zjeździe PZPR w marcu 1954 r., kiedy powrócono do struktury władz centralnych partii w kształcie, który obowiązywał bezpośrednio po wchłonięciu PPS przez PPR. W skład Sekretariatu BO wchodzili: Jakub Berman, Bolesław Bierut, Władysław Dworakowski (od czerwca do grudnia 1952 r.), Franciszek Mazur, Zenon Nowak (do grudnia 1952 r.), Edmund Pszczółkowski (od listopada 1952 r.) oraz Roman Zambrowski. Szerzej zob. K. Persak, Struktura i skład centralnych instancji decyzyjnych KC PZPR [w:] Centrum wladzy w Polsce 1948-1970, red. A. Paczkowski, Warszawa 2003, s. 19-50.

45 AAN, KC PZPR, V/17, Protokół nr 187 z posiedzenia Sekretariatu BO w dniu 14 VIII 1952 r., [b.m.], [b.p.].

46 Uchwała Rady Państwa z dnia 25 sierpnia 1952 r. w przedmiocie ustalenia podziału obszaru Państwa na okręgi wyborcze, liczby posłów, jaka ma być wybrana z każdego okręgu, oraz siedzib okręgowych komisji wyborczych, M. P. z 1952 r., nr A-72, poz. 1154. 
lenie do każdego okręgu minimum pięciu posłów pozwalało z kolei zapewnić, że na okręgowych listach wyborczych, zgodnie z propagandowym zamysłem Frontu Narodowego, będą reprezentowane różne środowiska i organizacje społeczne ${ }^{47}$. Natomiast, jak stwierdził na podstawie analizy rozkładu mandatów pomiędzy poszczególne okręgi w województwie krakowskim Sebastian Drabik, „dowartościowano te tereny (Chrzanów), które uważano za sprzyjające komunistom - nawet kosztem stolicy województwa"48. Wynikało to z założenia, że „przy tworzeniu okręgów wyborczych uwzględnia się tereny trudne, powiaty, które sprawiały dużo kłopotu w okresie akcji gospodarczych i politycznych" ${ }^{49}$.

Rada Państwa ogłosiła jednocześnie skład PKW, do której weszli: przewodniczący - Wacław Barcikowski (I prezes Sądu Najwyższego), zastępcy przewodniczącego - Paweł Wojas (wiceprzewodniczący Centralnej Rady Związków Zawodowych), Józef Ozga Michalski (przewodniczący Zarządu Głównego Związku Samopomocy Chłopskiej), sekretarz - Władysław Dworakowski (sekretarz KC PZPR) oraz członkowie - Szczepan Błaut (górnik), Mikołaj Dachow (wiceprezes Rady Naczelnej ZSL), Wanda Gościmińska (włókniarka), Stanisława Jankowska (sekretarz Zarządu Głównego Związku Zawodowego Nauczycielstwa Polskiego), Stefan Kalinowski (prokurator generalny), Józef Markow (murarz), Stanisław Mazur (chłop indywidualny), Jan Rabanowski (przewodniczący Rady Naczelnej SD), Stanisław Stachach (przewodniczący Zarządu Głównego Związku Zawodowego Pracowników Kolejowych), Zygfryd Sznek (działacz Związku Zawodowego Pracowników Państwowych), Zofia Wasilkowska (wiceprzewodnicząca Zarządu Głównego Ligi Kobiet), Tadeusz Wieczorek (sekretarz Zarządu Głównego Związku Młodzieży Polskiej) ${ }^{50}$. Członkostwo w PKW przedstawicieli różnych grup zawodowych i organizacji miało wymiar czysto propagandowy, miało świadczyć o ich rzekomym współudziale we władzy. W rzeczywistości byli oni jedynie figurantami. Podobnie jak w Związku Sowieckim, w PRL w różnego rodzaju gremiach kolegialnych (zarówno w Sejmie i radach narodowych, jak i w podmiotach zaangażowanych w przygotowanie wyborów) musiał jednak zostać zachowany określony parytet społeczno-zawodowy, który miał świadczyć o tym, że są one „demokratyczne” (bo jakoby odwzorowują społeczny przekrój ludności).

Aby w każdym okręgu zarejestrowana została tylko jedna lista wyborcza (firmować ją miał, zgodnie z pierwotnie proponowaną nazwą, Front Narodowy, o którym szerzej w dalszej części tekstu) ${ }^{51}$, komuniści musieli zadbać o odpowiedni dobór lu-

47 AAN, KC PZPR, V/23, Notatka w sprawie organizacji wyborów do Sejmu, Warszawa, 26 VII 1952 r., k. 57.

48 S. Drabik, Bezpieka i partia wobec wyborów do Sejmu PRL I kadencji w 1952 r. w województwie krakowskim, „Aparat Represji w Polsce Ludowej 1944-1989” 2013, nr 1 (11), s. 133.

49 AAN, KC PZPR, V/23, Notatka w sprawie organizacji..., k. 57.

50 Uchwała Rady Państwa z dnia 25 sierpnia 1952 r. w sprawie powołania Państwowej Komisji Wyborczej, M. P. z 1952 r., nr A-72, poz. 1153.

${ }^{51}$ Próby rejestracji konkurencyjnych wobec FN list wyborczych były podejmowane np. przez byłych działaczy PSL w Wielkopolsce, którzy w kilku powiatach próbowali opanować w tym celu struktury reżimowego ZSL; T. Rochatka, Aparat bezpieczeństwa w Wielkopolsce a wybory do sejmu w 1952 roku, „Pamięć i Sprawiedliwość” 2011, nr 2 (18), s. 283. 
dzi, którzy mieli o tym decydować. Władze partyjne przywiązywały zatem bardzo dużą wagę do składu okręgowych komisji wyborczych. Nie mniej uwagi poświęcano także komisjom obwodowym. Chociaż formalnie ich powoływanie należało do prezydiów rad narodowych, stosowne decyzje podejmowano w strukturach PZPR. Już po uchwaleniu ordynacji wyborczej do składu wspomnianej komisji organizacyjnej, odpowiadającej za sprawy personalne w kampanii wyborczej, z ramienia centralnych władz partyjnych dokooptowani zostali Mateusz Oks, Paweł Wojas i Julia Brystygier $^{52}$.

Kandydatury na członków okręgowych komisji wyborczych zatwierdzały komitety wojewódzkie partii, zaś obwodowych komisji wyborczych - komitety powiatowe przy udziale przedstawiciela Komitetu Wojewódzkiego. Szczególnie dbano o to, kto zajmował w poszczególnych komisjach stanowisko przewodniczącego. Osoby, które miały pełnić tę funkcję $\mathrm{w}$ obwodach, były zatwierdzane przez władze partii szczebla wojewódzkiego, zaś w okręgach przez sam Komitet Centralny. Musieli być to ludzie „doświadczeni” i „pewni politycznie" ${ }^{53}$. Istotną rolę w ich selekcji odgrywał aparat bezpieczeństwa publicznego.

Wybór, a raczej wyznaczenie kandydatów do komisji wyborczych - pisał Andrzej Zaćmiński otwierało dopiero właściwy proces ich weryfikacji. Toczył się on w gabinetach ubeckich, a jego istota sprowadzała się do lustracji pod kątem oblicza ideowo-politycznego. W każdym urzędzie bezpieczeństwa do tego celu wyznaczono pracowników odpowiedzialnych za poszczególne okręgis ${ }^{54}$.

Osoby „niepewne politycznie” były z komisji wykluczane. W ich ostatecznym składzie dominowali działacze PZPR. Na przykład w województwie bydgoskim na 4928 osób zasiadających w komisjach obwodowych do partii należało $2470(50,1 \%)$, w województwie poznańskim stopień upartyjnienia wynosił 64\% (4254 partyjnych na 6558$)^{55}$. Mimo iż nie istniały $w$ tej sprawie żadne formalne regulacje, instrukcji w sprawie działalności komisji wyborczych udzielały komitety wojewódzkie PZPR ${ }^{56}$.

„Odpowiedni” profil polityczny i dyspozycyjność ludzi dobieranych do aparatu wyborczego nie zawsze szły w parze $\mathrm{z}$ ich kompetencjami. W czasie odpraw aktywu zaangażowanego w przeprowadzenie wyborów stwierdzono np., że w Kętrzynie przewodniczący okręgowej komisji wyborczej nie rozumiał, czym różni się czynne i bierne prawo wyborcze, a w okręgu jarosławskim przewodniczący i zastępca przewodniczącego jednej z komisji obwodowych byli analfabetami, zaś sekretarz - półanalfabetą ${ }^{57}$. Pracownicy administracji lokalnej wykazywali się także innymi

52 AAN, KC PZPR, V/17, Protokół nr 185 z posiedzenia Sekretariatu BO w dniu 7 VIII 1952 r., [b.m.], [b.p.].

${ }_{53}$ AAN, KC PZPR, V/23, Notatka w sprawie organizacji..., k. 60.

${ }_{54}$ T. Wolsza, A. Zaćmiński, Ludzie listy pisza... Referendum i wybory do Sejmu w korespondencji Polaków (1946-1952), Bydgoszcz 2013, s. 209.

55 Ibidem, s. 209-210; T. Rochatka, s. 286.

56 Zob. np. AAN, Państwowa Komisja Wyborcza w Warszawie (dalej: PKW), 5, Sprawozdanie z pracy Państwowej Komisji Wyborczej za okres 1 X-22 X br., [b.m.d.], k. 92.

57 Ibidem, Sprawozdanie z pracy Państwowej Komisji Wyborczej w okresie 10-20 IX 1952 r., [b.m.d.], k. 82 . 
zaniedbaniami, które starano się naprawić podczas drobiazgowych kontroli wysyłanych w teren inspektorów PKW.

Prezydia rad narodowych - czytamy przykładowo w jednym ze sprawozdań rzeczonej instytucji - popełniły szereg zasadniczych błędów przy powoływaniu obwodowych komisji wyborczych. W szczególności zdarzały się wypadki powoływania do komisji osób nieżyjących (gm. Falników, pow. Kalisz), w Miastkowie (pow. Łomża) powołano do komisji chorego umysłowo, w gm. Chebrolewo (pow. Łomża) powołano do komisji kobietę w 9-tym m-cu ciąży ${ }^{58}$.

Taka niedbałość może świadczyć o tym, że wielu aparatczyków niższego szczebla nie przywiązywało większej wagi do rzetelnego przeprowadzenia wyborów, wychodząc ze słusznego skądinąd przekonania, że ich rezultat jest z góry przesądzony. Doświadczenie zakrojonych na szeroką skalę fałszerstw wyborczych w 1946 i 1947 roku dawało lokalnym działaczom pewność, że bez względu na zachowania wyborców oficjalne wyniki głosowania będą korzystne dla obozu władzy.

Sprawne przeprowadzenie kampanii wyborczej wymagało od władz PZPR dopilnowania także odpowiedniej obsady komitetów FN. Ostateczne decyzje w sprawie składu personalnego Ogólnopolskiego Komitetu Wyborczego FN podjęto na posiedzeniu Sekretariatu BO 25 sierpnia 1952 roku $^{59}$. Jego przewodniczącym został Bolesław Bierut, zastępcami przewodniczącego: Wiktor Kłosiewicz (przewodniczący Centralnej Rady Związków Zawodowych), Władysław Kowalski (prezes NKW ZSL) oraz Jan Dembowski (prezes Polskiej Akademii Nauk). Do prezydium weszli także: Jerzy Albrecht, Józef Cyrankiewicz, Leon Chajn, Dominik Horodyński, Stefan Ignar, Marian Jaworski, Aleksander Juszkiewicz, Henryk Kołodziejski, Leon Kruczkowski, Władysław Matwin, Jan Mrocheń, Alicja Musiałowa, Józef Niećko, Edward Ochab i Konstanty Rokossowski. Ponadto do OK FN wchodziło kilkadziesiąt osób reprezentujących rozmaite grupy społeczne i zawodowe, reżimowe organizacje itd. ${ }^{60}$ Podobnie jak w przypadku składu PKW, miało to tylko propagandowe znaczenie. FN nie stanowił, jak chciała komunistyczna propaganda, platformy porozumienia i współpracy różnych środowisk, a jedynie parawan, który przesłaniał kolejny fragment rzeczywistości, w którym de facto jedynym podmiotem decyzyjnym była PZPR. Nad jego programem wyborczym pracowała komisja partyjna w składzie: Jakub Berman (przewodniczący), Roman Werfel, Franciszek Fiedler, Zygmunt Modzelewski, Stefan Jędrychowski, Jerzy Tepicht, Leon Kasman, Stefan Staszewski, Julian Finkielsztejn, Marian Naszkowski, Jerzy Putrament, Jerzy Morawski, Artur Starewicz $^{61}$. Na wspomnianym posiedzeniu 25 sierpnia 1952 roku Sekretariat BO

58 Ibidem, Sprawozdanie z pracy Państwowej Komisji Wyborczej w okresie 20 IX br.-1 X br., [b.m.d.], k. 89.

59 AAN, KC PZPR, V/17, Protokół nr 189 z posiedzenia Sekretariatu BO w dniu 25 VIII 1952 r., [b.m.], [b.p.].

${ }^{60}$ AAN, KC PZPR, V/23, Skład Ogólnopolskiego Komitetu Wyborczego Frontu Narodowego, [b.m.d.], k. 41.

${ }^{61}$ AAN, KC PZPR, V/22, Załącznik nr 1 do protokołu [posiedzenia Sekretariatu BP w dniu 29 VII 1952 r.], nr 181, [b.m.d.], k. 21. 
podjął również decyzję o zwołaniu na 30 sierpnia krajowej konferencji FN, na której doszło do oficjalnego ukonstytuowania OKW FN ${ }^{62}$.

$\mathrm{Na}$ niższych szczeblach, podobnie jak w przypadku komisji wyborczych, szczególnie zaufanymi ludźmi musieli być przewodniczący komitetów FN, od których wymagano wypełnienia ośmiostronicowej ankiety personalnej oraz pozytywnej opinii właściwego terytorialnie urzędu bezpieczeństwa publicznego ${ }^{63}$. Byli oni zatwierdzani przez odpowiednie władze partyjne (komitety wojewódzkie i powiatowe partii). Bieżące kierowanie kampanią wyborczą należało do wchodzących w skład struktur FN zespołów przedstawicieli PZPR ${ }^{64}$.

Ostatnim krokiem, który miał zapewnić PZPR całkowitą kontrolę nad składem przyszłego Sejmu, było ułożenie list kandydatów na posłów. To na tym etapie przygotowania wyborów, zgodnie z sowieckim wzorcem, decydowano de facto o tym, kto znajdzie się w Sejmie. Choć konstytucja i ordynacja wyborcza wskazywały cały szereg podmiotów, które mogły zgłaszać kandydatury poselskie, w praktyce kandydaci byli zgłaszani na zebraniach komitetów $\mathrm{FN}^{65}$. Nie mogło być przy tym mowy o żadnej niezależnej inicjatywie. W cytowanej już notatce do projektu ordynacji wyborczej z góry założono, że kandydaci, którzy oficjalnie zostaną zaproponowani „oddolnie”, będą zawczasu ustaleni w ramach „bloku”, w którym tzw. stronnictwa sojusznicze były całkowicie kontrolowane przez PZPR ${ }^{66}$. Dbano jednak o zachowanie pozorów.

Na zebraniach wysunąć można - czytamy dalej w rzeczonym dokumencie - znacznie więcej kandydatur, aniżeli wynosi ilość mandatów w okręgu. W szczególności obok właściwych kandydatów, wysuwanych z reguły przez kilka organizacji, zakładów pracy, itp. wysuwa się też kierowników partii [członków kierownictwa partyjnego - przyp. M.S.]. Jednakże zgodę swą na zarejestrowanie dają każdy tylko dla jednego okręgu (art. 56 ust. 1), wobec czego kandydatury ich w innych okręgach odpadają i pozostają do zarejestrowania tylko właściwi kandydaci danego okręgu, i to ściśle w tej liczbie, ile jest mandatów do obsadzenia ${ }^{67}$.

Podobną praktykę stosowano w Związku Sowieckim, gdzie liczba okręgów, z których wysunięto daną kandydaturę (choć ostatecznie mogła ostać się tylko w jednym okręgu), miała świadczyć o randze danego przywódcy partyjnego ${ }^{68}$. O rzekomym

62 AAN, KC PZPR, V/17, Protokół nr 189...

63 J. Sudoł, Wybory do Sejmu z dnia 26 X 1952 r.w województwie bydgoskim, Bydgoszcz 2003, s. 47, praca magisterska przygotowana pod kierunkiem prof. dr. hab. Andrzeja Zaćmińskiego, obroniona na Wydziale Humanistycznym Akademii Bydgoskiej im. Kazimierza Wielkiego, za udostępnienie maszynopisu dziękuję prof. Andrzejowi Zaćmińskiemu.

${ }_{64}$ AAN, KC PZPR, V/23, Notatka w sprawie organizacji..., k. 57-59; AAN, KC PZPR, V/22, Wytyczne dla KW i KP w sprawie przygotowań do kampanii wyborczej (projekt), [b.m. Warszawa], sierpień 1952 r., k. 322.

${ }_{65}$ J. Olejniczak, Wybory do Sejmu i rad narodowych $w$ województwie bydgoskim $w$ okresie tzw. małej stabilizacji (1956-1970), Torun 2010, s. 178.

${ }^{66}$ AAN, KC PZPR, V/21, Notatka do projektu...

${ }^{67}$ Ibidem. Zob. też: S. Stępka, Władze partyjno-państwowe a chlopi w okresie wyborów (19471957) [w:] Represje wobec wsi i ruchu ludowego (1944-1956). Materiaty z konferencji naukowej 5-6 grudnia 2002 r. w Rzeszowie, t. 1, red. J. Gmitruk, Z. Nawrocki, Warszawa 2003, s. 54.

68 G. Brunner, op. cit., s. 34-35. 
powszechnym poparciu dla sowieckich dyktatorów miały świadczyć też różne inne, niekiedy wręcz absurdalne, objawy. Na przykład otaczany krytykowanym później „kultem jednostki” Józef Stalin, kandydując w 1937 roku do Rady Najwyższej ZSRS z Moskwy, uzyskał oficjalnie ponad 100\% głosów, co thumaczono faktem, że oddawano na niego głosy także w sąsiednich okręgach wyborczych ${ }^{69}$.

Elementem „importowanego” systemu politycznego w Polsce był kult Stalina także nad Wisłą ${ }^{70}$ oraz - jako rodzimego przywódcy - Bolesława Bieruta ${ }^{71}$. W raportach z przebiegu przygotowań do wyborów w 1952 roku, składanych partyjnej centrali, lokalni działacze prześcigali się więc $\mathrm{w}$ opisywaniu rozmiarów poparcia na ich terenie dla wspomnianych „kierowników partii” na czele z Bierutem, popadając niekiedy w ton wręcz groteskowy.

Na zebraniach masowych w zakładach pracy - czytamy przykładowo w sprawozdaniu Wojewódzkiego Komitetu FN w Katowicach - na których wysuwano kandydatów na posłów i ich zastępców do Sejmu PRL, wyborcy w całej pełni wyrazili swoje przywiązanie i zaufanie do Centralnych Kandydatów na czele z Prezydentem Bolesławem Bierutem, podkreślając w wypowiedziach swoją miłość i zaufanie do pierwszego obywatela ${ }^{72}$.

„Spontanicznie” wysunięte na zebraniach FN kandydatury były następnie dodatkowo korygowane przez komitety wojewódzkie i KC PZPR ${ }^{73}$. Decyzje w sprawie składu personalnego Sejmu PRL I kadencji podejmowano na długo przed wyborami - Sekretariat BP KC PZPR zajmował się tymi sprawami na posiedzeniach w dniach 5 i 11 września 1952 roku. Na drugim ze wspomnianych posiedzeń, rozpatrując proponowanych kandydatów na posłów, kierownictwo partii przyjęło jednocześnie instrukcję w sprawie ich wysuwania w terenie ${ }^{74}$. Ponieważ w Związku Sowieckim na listy wyborcze trafiali nie tyle kandydaci „najlepsi”, ile „odpowiedni”" ${ }^{\prime 5}$ (oczywiście z perspektywy kierownictwa partii komunistycznej), nie inaczej musiało być w PRL.

W tej sytuacji próby niezależnego od partii zgłaszania kandydatur, cieszących się popularnością w lokalnych środowiskach, na listy FN, nie miały szans na powodzenie. Do takich przypadków należy przykład Czesława Skowrońskiego - weterynarza z Żychlina, którego na kandydata na posła wysuwała miejscowa ludność (list, w którym proponowano jego kandydaturę podpisali sołtysi kilkudziesięciu wsi) ${ }^{76}$.

69 S. White, Reforming the Electoral System, „Journal of Communist Studies” 1988, nr 4, vol. 4, s. 3 .

70 Szerzej zob. m.in. R. Kupiecki, „, Natchnienie milionów”. Kult Józefa Stalina w Polsce 19441956, Warszawa 1993.

71 M. Zaremba, Drugi stopień drabiny. Kult pierwszych sekretarzy w Polsce [w:] PRL. Trwanie..., s. 41; J. Eisler, Siedmiu wspaniałych. Poczet pierwszych sekretarzy KC PZPR, Warszawa 2014, s. 82.

72 AAN, Biuro Ogólnopolskiego Komitetu Frontu Narodowego w Warszawie (dalej: BOKFN), 14, Sprawozdanie Wojewódzkiego Komitetu Frontu Narodowego z wyborów, Katowice, 7 XI 1952 r., [b.p.].

73 J. Olejniczak, op. cit., s. 178.

${ }^{74}$ AAN, KC PZPR, V/17, Protokół nr 191 z posiedzenia Sekretariatu BP w dniu 5 września 1952 r., [b.m.], [b.p.]; ibidem, Protokół nr 192 z posiedzenia Sekretariatu BP w dniu 11 września 1952 r., [b.m.], [b.p.].

75 Zob. M.E. Mote, op. cit., s. 27-31.

76 AAN, BOKFN, 86, List do Centralnego Frontu Narodowego w Warszawie, Żychlin, 6 X 1952 r., k. 54-56. 
Skowroński nie miał jednak wystarczającego zaufania władz partyjnych, aby zostać posłem ${ }^{77}$.

Odwrotną sytuację - kiedy partia przeforsowała do Sejmu swojego zaufanego kandydata, którego przeszłość mogła budzić wśród wyborców wątpliwości - opisał zbiegły pod koniec 1953 roku na Zachód były wicedyrektor Departamentu X MBP Józef Światło ${ }^{78}$. Jego zdaniem jeden z kandydatów na posłów z Częstochowy w przeszłości został sądownie skazany za morderstwo. O jego wysunięciu miał rozsądzić ostatecznie sam Bolesław Bierut, który zadowolił się informacją, że fakt ten nie był szerzej znany częstochowianom ${ }^{79}$.

W swoich wypowiedziach dla Radia Wolna Europa Światło poruszył także inną istotną kwestię - roli, jaką odgrywał w selekcji kandydatów na listy wyborcze FN Departament X MBP ${ }^{80}$ i terenowe komórki aparatu bezpieczeństwa. Według jego relacji partia przesyłała do Departamentu X spis proponowanych kandydatur, które były następnie szczegółowo analizowane. Każdy proponowany kandydat był sprawdzany w kartotekach MBP i sądowych rejestrach skazanych, następnie pracownik WUBP przeprowadzał z nim wywiad i wypełniał na jego temat drobiazgową ankietę, obejmującą zarówno dane na temat wykształcenia, dotychczasowej działalności politycznej, jak i życia prywatnego. Ankiety były dodatkowo weryfikowane już w samym Departamencie X w Warszawie, który wydawał ostateczną opinię na temat każdego kandydata ${ }^{81}$. „W praktyce sprowadza się to do tego - podsumowywał Światło - że partia stawia wniosek i daje listę kandydatów, a dziesiąty departament po przeprowadzeniu najdokładniejszych badań zatwierdza kandydata, albo go odrzuca. Jeżeli my go odrzucimy, to naród na pewno go nie wysunie"»2. Były funkcjonariusz przerysowywał znaczenie swojego departamentu, przypisując mu kompetencje właściwej instancji władczej, którą w rzeczywistości było kierownictwo PZPR. Chociaż odwrócił proporcje wpływu poszczególnych podmiotów w procesie decyzyjnym, nie ulega jednak wątpliwości, że partia korzystała z „pomocy” MBP przy ustalaniu list kandydatów na posłów.

W zgodzie z praktykami wyborczymi ZSRS kandydatury proponowane przez instancje partyjne w terenie, abstrahując od wymogu „sprawdzenia” każdej propozycji przez organa bezpieczeństwa i akceptacji przez partyjną centralę, musiały odpowiadać wspominanemu już parytetowi - określonemu przez władze PZPR projektowi podziału mandatów pomiędzy różne grupy zawodowe i społeczne. W Sejmie PRL

77 Archiwum danych o postach, http://orka.sejm.gov.p1/ArchAll2.nsf [dostęp: 16.02.2015].

78 Na temat tej niejednoznacznej postaci szerzej pisał Andrzej Paczkowski. Zob. idem, Trzy twarze Józefa Światly. Przyczynek do historii komunizmu w Polsce, Warszawa 2009.

79 Z. Błażyński, Mówi Józef Światto. Za kulisami bezpieki i partii 1940-1955, Warszawa 1990, s. 191.

80 Szerzej zob. m.in. Departament X MBP. Wzorce - struktury - działanie, red. K. Rokicki, Warszawa 2007; R. Spałek, Komuniści przeciwko komunistom. Poszukiwanie wroga wewnętrznego w kierownictwie partii komunistycznej w Polsce w latach 1948-1956, Warszawa-Poznań 2014; J. Topyło, Departament X MBP w latach 1949-1954. Geneza - struktura organizacyjna - metody pracy, Toruń 2006.

81 Z. Błażyński, op. cit., s. 190-191.

82 Ibidem, s. 191. 
I kadencji miało zatem znaleźć się 100 posłów reprezentujących przemysł (w tym 70 robotników oraz 30 techników i inżynierów), 70 - rolnictwo (w tym 40 - spółdzielnie produkcyjne, 20 - indywidualne gospodarstwa rolne oraz 10 - Państwowe Ośrodki Maszynowe i Państwowe Gospodarstwa Rolne), 55 - inteligencję (w tym 15 nauczycieli i 5 lekarzy), 25 - rady narodowe, 30 - aparat partyjny PZPR, 25 - aparat związków zawodowych, 10 - aparat Związku Młodzieży Polskiej, 50 - Radę Państwa i rząd, 30 - władze naczelne PZPR, 15 - władze naczelne ZSL, 5 - władze naczelne SD, 8 - władze naczelne „organizacji masowych”. Liczbę przyszłych posłanek określono orientacyjnie na 80-90, zaś posłów „młodzieżowych” na $40^{83}$. Znaczącą część kandydatów (przeszło 1/3) stanowili tzw. kandydaci centralni, tzn. osoby wyznaczone do kandydowania w poszczególnych województwach przez samo centralne kierownictwo PZPR ${ }^{84}$. Zdarzały się okręgi, w których stanowili oni większość kandydatów. Tak było np. w okręgu nr 63 z siedzibą w Chrzanowie, z którego kandydowali: Witold Bierawski, Maria Iskra, Józef Karweta, Jerzy Pryma, Jan Pypeć, Jan Szkop i Kazimierz Wyka. Z grona tego tylko Wyka i Karweta mieli coś wspólnego z ziemią chrzanowską ${ }^{85}$. Według ustalonego zawczasu w kierownictwie PZPR ogólnego parytetu politycznego ponad 270 mandatów miało przypaść w udziale członkom partii, 90 - ZSL, 25 - SD, 5 - „postępowym” katolikom, 77 - bezpartyjnym ${ }^{86}$. Ostateczny podział mandatów został nieco zmodyfikowany, gdyż planowana pierwotnie liczba 467 posłów została zmniejszona do 425, w tym 273 z PZPR, 90 z ZSL, 25 z SD i 37 bezpartyjnych (w tym tzw. postępowych katolików) ${ }^{87}$.

Wobec omówionych powyżej działań kampania wyborcza przed wyborami do Sejmu PRL I kadencji oraz samo głosowanie 26 października 1952 roku $^{88}$ nie mogły

83 AAN, KC PZPR, V/23, Proponowany przekrój [społeczno-zawodowy Sejmu PRL I kadencji], [b.m.d.], k. 50 .

${ }^{84}$ AAN, KC PZPR, V/23, Zestawienie statystyczne kandydatów wg województw, [b.m.d.], k. 187.

85 Wybory 1952 czyli wybieranie wybranych, ,Przelom.pl. Portal Ziemi Chrzanowskiej”, http://przelom.pl/14677-wybory-1952-czyli-wybieranie-wybranych.html [dostęp: 15.02.2015].

86 Notatka z dziennika I sekretarza Ambasady ZSRS w Warszawie Piotra Turpitko o przebiegu rozmowy z kierownikiem Wydziału Kadr KC PZPR Kazimierzem Witaszewskim, dotyczącej kampanii wyborczej do Sejmu PRL, wyłaniania kandydatów na posłów spośród byłych prawicowych działaczy PPS i sytuacji kadrowej w kierownictwie państwa, Warszawa, 24 IX 1952 r. [w:] Polska w dokumentach $z$ archiwów rosyjskich 1949-1953, wybór i oprac. A. Kochański, G.P. Muraszko, A.F. Noskowa, A. Paczkowski, K. Persak, thum. E. Rosowska, Warszawa 2000, s. 160.

${ }^{87}$ Historia sejmu polskiego, red. A. Ajnenkiel, t. III: J. Zakrzewska, T. Mołdawa, Polska Ludowa, Warszawa 1989, s. 304.

88 Szerzej zob. J. Wojsław, Kampania propagandowa towarzyszaca wyborom do Sejmu z 26 października 1952 roku, „Polska 1944/45-1989. Studia i Materiały” 2010, nr 9, s. 133-153; idem, Strategie propagandowe w latach apogeum stalinizmu na przyktadzie wyborów do Sejmu z 26 października 1952 r.: język tekstu i obrazu [w:] Wybory i referenda..., s. 455-488; A. Zaćmiński, Duchowieństwo Kościoła katolickiego w województwie bydgoskim wobec ,wyborów” do Sejmu PRL: z 26 X 1952 roku, „Zapiski Historyczne” 2009, t. LXXIV, z. 3, s. 61-76; J. Tyszkiewicz, Propaganda wyborów do Sejmu PRL w 1952 roku na tamach prasy wroctawskiej [w:] Obraz wyborów w prasie XIX i XX wieku na Pomorzu, Ślasku i w Wielkopolsce, red. A. Chlebowska, J. Nowosielska-Sobel, Szczecin 2007, s. 347-361; A. Hutnikiewicz, Obraz wyborów parlamentarnych w latach 1947 i 1952 w prasie szczecińskiej [w:] Obraz wyborów w prasie..., s. 331-346; D. Gałaszewski, Wizerunek agitatorów domowych ZMP w spolecznym odbiorze wyborów 1952 r. [w:] Studia i materiały z dziejów opozycji i oporu 
doprowadzić do zmiany ustalonego zawczasu przez partyjnych decydentów scenariusza, zgodnie z którym fotele poselskie zostały rozdysponowane dużo wcześniej. Podobnie jak w Związku Sowieckim, w poprzedzającej wybory kampanii chodziło już nie o rywalizację poszczególnych kandydatów, a o indoktrynację i mobilizację społeczeństwa do aktywnego poparcia komunistycznych władz. Stanowiła ona pretekst do podjęcia z jednej strony zakrojonych na szeroką skalę działań propagandowych, a z drugiej represyjnych, które miały zmusić obywateli do masowego udziału w wyborczej farsie. Oficjalne wyniki głosowania, w których dla władz liczyła się przede wszystkim jak najwyższa frekwencja (według obwieszczenia PKW z 28 października 1952 r. wyniosła ona 95,03\% ${ }^{89}$ ) - także i w tej kwestii polscy komuniści wzorowali się na swoich sowieckich zwierzchnikach - były następstwem zarówno natężonej indoktrynacji społeczeństwa (po części skutecznej), jak i zastraszenia obywateli przez aparat bezpieczeństwa oraz manipulacji i zwyczajnych fałszerstw wyborczych ${ }^{90}$.

Skład parlamentu „wybranego” jesienią 1952 roku został przesądzony na długo przed dniem głosowania, podczas układania list wyborczych Frontu Narodowego. Jeśli dana osoba na liście się znalazła, jej „wybór”, wobec braku kontrkandydatów, był właściwie pewien. Tym samym wdrożono w Polsce system wyborczy oparty na rozwiązaniach stosowanych w Związku Sowieckim, w którym kluczowe znaczenie przy obsadzie foteli poselskich miały reguły wyłaniania kandydatów na posłów, na które składały się przepisy prawa wyborczego, wewnątrzpartyjne instrukcje oraz rzeczywiste schematy postępowania obejmujące szereg nieformalnych działań, zapewniających PZPR kontrolę nad składem izby, a PRL w kolejnym aspekcie upodobniła do ZSRS. Generalną cechą charakterystyczną tego systemu była swoista dychotomia: z pozoru demokratyczne przepisy prawne rozmijały się ze skrajnie niedemokratycznymi praktykami.

Mechanizmy wykorzystane przez władze przy organizacji głosowania w 1952 roku, takie jak rejestracja tylko jednej listy wyborczej i nacisk na głosowanie bez skreśleń, na trwałe wpisały się do katalogu praktyk wyborczych, które były stosowane w PRL w kolejnych latach ${ }^{91}$ pomimo zasadniczej zmiany realiów politycznych, jak również zasad prawa wyborczego. Wdrożono wówczas w życie zasadniczy schemat

społecznego, t. 4, red. Ł. Kamiński, Wrocław 2000, s. 130-139; M. Mazur, Strategie perswazyjne w wyborach do Sejmu w latach 1947, 1952, 1957. Model porównawczy [w:] Wybory i referenda..., s. 489-507; T. Rochatka, op. cit., s. 275-298; S. Drabik, op. cit., s. 129-161; T. Wolsza, A. Zaćmiński, op. cit., s. 199-268.

${ }_{89}$ Obwieszczenie Państwowej Komisji Wyborczej z dnia 28 października 1952 r. w sprawie wyników wyborów do Sejmu Polskiej Rzeczypospolitej Ludowej w dniu 26 października 1952 r., M. P. 1952, nr A-91, poz. 1414.

90 Szerzej zob. M. Siedziako, Manipulacje i fatszerstwa wyborcze w wyborach do Sejmu PRL (1952-1985), „Pamięć i Sprawiedliwość” 2016, nr 1 (27), s. 112-139.

${ }_{91}$ Szerzej zob. m.in.: Wybory i referenda...; M. Siedziako, Partia wybiera, spoleczeństwo glosuje. Jak wytaniano Sejm PRL (1952-1985) [w:] Elity komunistyczne w Polsce, red. M. Szumiło, M. Żukowski, Warszawa-Lublin 2015, s. 192-223; idem, Mechanizmy kontroli PZPR nad sktadem Sejmu PRL (1952-1985) [w:] Partia, państwo, spoleczeństwo, red. K. Rokicki, Warszawa 2016, s. 158 201 oraz literatura przywoływana w powyższych pracach. 
organizacji wyborów, który aż po schyłek funkcjonowania dyktatury komunistycznej w Polsce nie został zastąpiony żadnym innym, a podlegał jedynie pewnym kosmetycznym modyfikacjom.

\section{BIBLIOGRAFIA}

\section{Archiwa}

Archiwum Akt Nowych:

- Biuro Ogólnopolskiego Komitetu Frontu Narodowego w Warszawie;

- Komitet Centralny Polskiej Zjednoczonej Partii Robotniczej;

- Państwowa Komisja Wyborcza w Warszawie.

\section{Akty prawne i druki urzędowe}

Konstytucja Polskiej Rzeczypospolitej Ludowej uchwalona przez Sejm Ustawodawczy w dniu 22 lipca 1952 r., Dz. U. z 1952 r., nr 33, poz. 232.

Obwieszczenie Państwowej Komisji Wyborczej z dnia 28 października 1952 r. w sprawie wyników wyborów do Sejmu Polskiej Rzeczypospolitej Ludowej w dniu 26 października 1952 r., M. P. 1952, nr A-91, poz. 1414.

Uchwała Rady Państwa z dnia 25 sierpnia 1952 r. w przedmiocie ustalenia podziału obszaru Państwa na okręgi wyborcze, liczby posłów, jaka ma być wybrana z każdego okręgu, oraz siedzib okręgowych komisji wyborczych, M. P. z 1952 r., nr A-72, poz. 1154.

Uchwała Rady Państwa z dnia 25 sierpnia 1952 r. w sprawie powołania Państwowej Komisji Wyborczej, M. P. z 1952 r., nr A-72, poz. 1153.

Uchwała Rady Państwa z dnia 5 VIII 1952 r. o zarządzeniu wyborów do Sejmu Polskiej Rzeczypospolitej Ludowej, Dz. U. z 1952 r., nr 35, poz. 247.

Ustawa z dnia 1 sierpnia 1952 r. Ordynacja wyborcza do Sejmu Polskiej Rzeczypospolitej Ludowej, Dz. U. z 1952 r., nr 35, poz. 246.

\section{3. Źródła publikowane}

Błażyński Z., Mówi Józef Światto. Za kulisami bezpieki i partii 1940-1955, Warszawa 1990. Konstytucja (ustawa zasadnicza) Związku Socjalistycznych Republik Radzieckich z dn. 5 XII 1936 r. [w:] A. Bosiacki, H. Izdebski, Konstytucjonalizm rosyjski. Historia i wspótczesność, Kraków 2013.

Polska $w$ dokumentach z archiwów rosyjskich 1949-1953, wybór i oprac. A. Kochański, G.P. Muraszko, A.F. Noskowa, A. Paczkowski, K. Persak, thum. E. Rosowska, Warszawa 2000. 
Wolsza T., Zaćmiński A., Ludzie listy pisza... Referendum i wybory do Sejmu w korespondencji Polaków (1946-1952), Bydgoszcz 2013.

\section{Prace niepublikowane}

Sudoł J., Wybory do Sejmu z dnia 26 X 1952 r. w województwie bydgoskim, Bydgoszcz 2003 (mps pracy magisterskiej przygotowanej na Wydziale Humanistycznym Akademii Bydgoskiej im. Kazimierza Wielkiego pod kierunkiem prof. dr. hab. Andrzeja Zaćmińskiego, w zbiorach autora).

\section{Prace zbiorowe, monografie i artykuły naukowe}

Brunner G., Elections in the Soviet Union [w:] Elections in Socialist States, red. R.K. Furtak, New York 1990.

Departament X MBP. Wzorce - struktury - działanie, red. K. Rokicki, Warszawa 2007.

Drabik S., Bezpieka i partia wobec wyborów do Sejmu PRL I kadencji w 1952 r. w województwie krakowskim, „Aparat Represji w Polsce Ludowej 1944-1989” 2013, nr 1 (11).

Eisler J., Siedmiu wspaniatych. Poczet pierwszych sekretarzy KC PZPR, Warszawa 2014.

Friedgut T.H., Political Participation in the USSR, Princeton 1979.

Gałaszewski D., Wizerunek agitatorów domowych ZMP w społecznym odbiorze wyborów 1952 r. [w:] Studia i materiały z dziejów opozycji i oporu społecznego, t. 4, red. Ł. Kamiński, Wrocław 2000.

Garlicki A., Stalinizm, Warszawa 1993.

Historia sejmu polskiego, red. A. Ajnenkiel, t. III: J. Zakrzewska, T. Mołdawa, Polska Ludowa, Warszawa 1989.

Hutnikiewicz A., Obraz wyborów parlamentarnych w latach 1947 i 1952 w prasie szczecińskiej [w:] Obraz wyborów w prasie XIX i XX wieku na Pomorzu, Śląsku i w Wielkopolsce, red. A. Chlebowska, J. Nowosielska-Sobel, Szczecin 2007.

Jarosz D., Polacy a stalinizm 1948-1956, Warszawa 2000.

Karklins R., Soviet Elections Revisited: Voter Abstention in Noncompetitive Voting, „American Political Science Review” 1986, vol. 80, nr 2.

Kupiecki R., ,Natchnienie milionów”. Kult Józefa Stalina w Polsce 1944-1956, Warszawa 1993.

Mazur M., Strategie perswazyjne w wyborach do Sejmu w latach 1947, 1952, 1957. Model porównawczy [w:] Wybory i referenda w PRL, red. S. Ligarski, M. Siedziako, Szczecin 2014.

Mażewski L., Posttotalitarny autorytaryzm PRL 1956-1989. Analiza ustrojowopolityczna, Warszawa-Biała Podlaska 2011.

Mażewski L., System rząów w PRL (1952-1989), Warszawa-Biała Podlaska 2011.

Mote M.E., Soviet Local and Republic Elections: A Description of the 1963 Elections in Leningrad Based on Official Documents, Press Accounts, and Private Interviews, Stanford 1965.

Motyka G., Na biatych Polaków obława. Wojska NKWD $w$ walce z polskim podziemiem 1944-1953, Kraków 2014. 
Olejniczak J., Wybory do Sejmu i rad narodowych $w$ województwie bydgoskim w okresie tzw. małej stabilizacji (1956-1970), Toruń 2010.

Paczkowski A., Trzy twarze Józefa Światty. Przyczynek do historii komunizmu w Polsce, Warszawa 2009.

Persak K., ,, Troskliwy opiekun i światty doradca Polski Ludowej”. Poprawki Józefa Stalina do Konstytucji PRL z 22 lipca 1952 roku [w:] PRL. Trwanie i zmiana, red. D. Stola, M. Zaremba, Warszawa 2003.

Persak K., Struktura i skład centralnych instancji decyzyjnych KC PZPR [w:] Centrum władzy w Polsce 1948-1970, red. A. Paczkow ski, Warszawa 2003.

Polacy wobec PRL. Strategie przystosowawcze, red. G. Miernik, Kielce 2003.

Polacy wobec przemocy 1944-1956, red. B. Otwinowska, J. Żaryn, Warszawa 1996.

Rochatka T., Aparat bezpieczeństwa w Wielkopolsce a wybory do sejmu w 1952 roku, „Pamięć i Sprawiedliwość" 2011, nr 2 (18).

Siedziako M., Manipulacje i fatszerstwa wyborcze w wyborach do Sejmu PRL (1952-1985), „Pamięć i Sprawiedliwość” 2016, nr 1 (27).

Siedziako M., Mechanizmy kontroli PZPR nad składem Sejmu PRL (1952-1985) [w:] Partia, państwo, społeczeństwo, red. K. Rokicki, Warszawa 2016.

Siedziako M., Partia wybiera, społeczeństwo głosuje. Jak wyłaniano Sejm PRL (19521985) [w:] Elity komunistyczne w Polsce, red. M. Szumiło, M. Żukowski, WarszawaLublin 2015.

Sokół W., Systemy wyborcze w Polsce Ludowej - uwarunkowania, mechanizmy i konsekwencje polityczne [w:] Wybory i referenda $w$ PRL, red. S. Ligarski, M. Siedziako, Szczecin 2014.

Spałek R., Komuniści przeciwko komunistom. Poszukiwanie wroga wewnętrznego w kierownictwie partii komunistycznej w Polsce w latach 1948-1956, Warszawa-Poznań 2014.

Stępka S., Władze partyjno-państwowe a chtopi w okresie wyborów (1947-1957) [w:] Represje wobec wsi i ruchu ludowego (1944-1956). Materiaty z konferencji naukowej 5-6 grudnia 2002 r. w Rzeszowie, t. 1, red. J. Gmitruk, Z. Nawrocki, Warszawa 2003.

Szumiło M., Roman Zambrowski 1909-1977. Studium z dziejów elity komunistycznej w Polsce, Warszawa 2014.

Świda-Ziemba H., Człowiek wewnętrznie zniewolony. Problemy psychosocjologiczne minionej formacji, Warszawa 1998.

Topyło J., Departament X MBP w latach 1949-1954. Geneza - struktura organizacyjna metody pracy, Torun 2006.

Tyszkiewicz J., Propaganda wyborów do Sejmu PRL w 1952 roku na łamach prasy wrocławskiej [w:] Obraz wyborów w prasie XIX i XX wieku na Pomorzu, Ślasku i w Wielkopolsce, red. A. Chlebowska, J. Nowosielska-Sobel, Szczecin 2007.

Werblan A., Stalinizm w Polsce, Warszawa 2009.

White S., Reforming the Electoral System, „Journal of Communist Studies” 1988, vol. 4, nr 4.

Wojsław J., Kampania propagandowa towarzyszaca wyborom do Sejmu z 26 października 1952 roku, „Polska 1944/45-1989. Studia i Materiały” 2010, nr 9.

Woj sław J., Strategie propagandowe w latach apogeum stalinizmu na przykładzie wyborów do Sejmu z 26 października 1952 r.: język tekstu i obrazu [w:] Wybory i referenda w PRL, red. S. Ligarski, M. Siedziako, Szczecin 2014.

Wrona J., System partyjny w Polsce 1944-1950. Miejsce - funkcje - relacje partii politycznych $w$ warunkach budowy i utrwalania systemu totalitarnego, Lublin 1997.

Wybory i referenda w PRL, red. S. Ligarski, M. Siedziako, Szczecin 2014. 
Zaćmiński A., Duchowieństwo Kościoła katolickiego w województwie bydgoskim wobec „,wyborów” do Sejmu PRL: z 26 X 1952 roku, „Zapiski Historyczne” 2009, t. LXXIV, z. 3.

Zaremba M., Drugi stopień drabiny. Kult pierwszych sekretarzy w Polsce [w:] PRL. Trwanie i zmiana, red. D. Stola, M. Zaremba, Warszawa 2003.

Zaslavsky V., Brym R.J., The Functions of Elections in the USSR, „Soviet Studies” 1978, t. $30, \mathrm{nr} 3$.

\section{Internet}

Archiwum danych o posłach, http://orka.sejm.gov.pl/ArchAll2.nsf [dostęp: 16.02.2015].

Sprawozdanie stenograficzne z 108 posiedzenia Sejmu Ustawodawczego w dniach 31 lipca i 1 sierpnia 1952 r., Warszawa 1952 [w:] Sejm Ustawodawczy RP 1947-1952, https:// bs.sejm.gov.pl/F?func=file\&file_name=find-nowe-sur\&local_base=ars01 [dostęp: 10.01 . 2016].

Sprawozdanie stenograficzne z 99 posiedzenia Sejmu Ustawodawczego w dniu 15 grudnia 1951 r., Warszawa 1951 [w:] Sejm Ustawodawczy RP 1947-1952, https://bs.sejm.gov. $\mathrm{pl} / \mathrm{F}$ ?func=file\&file_name=find-nowe-sur\&local_base=ars01 [dostęp: 10.01.2016].

Wybory 1952 czyli wybieranie wybranych, „Przelom.pl. Portal Ziemi Chrzanowskiej”, http:// przelom.pl/14677-wybory-1952-czyli-wybieranie-wybranych.html [dostęp: 15.02.2015]. 